\title{
Eksistensi Konselor: Manifestasi Pendidikan Era Millenial
}

\author{
Yaumil Afiat ${ }^{1 *}$ \\ ${ }^{1}$ Institut Agama Islam Negeri Batusangkar. \\ *Korespondensi: yaumilafiat78@gmail.com
}

\begin{abstract}
Guidance and counseling is an integral part of education. Through education, it is expected that students as a generation of millennial will be able to become creative and innovative people. In order to realize the goals of education, counselors in the delivery of services in schools contribute and contribute in efforts to help students carry out their developmental tasks. The ability of students in the millennial is accompanied by the competence of counselors in performance in the field as a manifestation of education in schools. This paper give an idea of how the existence of counselors in the millennial to realize the goals of education
\end{abstract}

Keywords: Counselor, Millenial, Education.

\begin{abstract}
Abstrak
Bimbingan dan konseling merupakan bagian yang integral dalam pendidikan. Melalui pendidikan, diharapkan siswa sebagai generasi era milenial mampu menjadi insan yang kreatif dan inovatif. Dalam rangka mewujudkan tujuan pendidikan, konselor dalam penyelenggaraan layanan di sekolah berkontribusi dan ikut andil dalam upaya membantu siswa melaksanakan tugas perkembangannya. Kemampuan siswa di era milenial selanjutnya diiringi dengan kompetensi konselor dalam unjuk kerja di lapangan sebagai manifestasi pendidikan di sekolah. Tulisan ini mencoba memberikan gagasan bagaimana eksistensi konselor di era milenial dalam rangka mewujudkan tujuan pendidikan
\end{abstract}

Kata Kunci: Konselor, Era Millenial, Pendidikan

How To Cite : Afiat, Y., (2020). Eksistensi Konselor: Manifestasi Pendidikan Era Millenial. Biblio Couns: Jurnal Kajian Konseling dan Pendidikan, 3(2), 50-55.

This is an open access article distributed under the Creative Commons 4.0 Attribution License, which permits unrestricted use, distribution, and reproduction in any medium, provided the original work is properly cited.@2020 by author

\section{PENDAHULUAN}

Istilah "era milenial" sudah tidak asing lagi terdengar di khayalak ramai. Apabila ditelusuri lebih jauh, istilah era millennial ini berasal dari kata millennials yang diciptakan oleh dua pakar sejarah dan penulis Amerika, yaitu William Strauss dan Neil Howe. Dalam literatur Wikipedia, para peneliti mengklasifikasikan generasi milenial ini dari awal kelahiran 1980-an, pertengahan tahun 1990-an hingga awal 2000-an sebagai akhir kelahiran. Klasifikasi ini menunjukkan bahwa era millenial ini merupakan gerenasi yang lahir pada rentangan tahun 1980 hingga 2000. Berdasarkan klasifikasi ini, dapat dipaparkan bahwa generasi millennial ini adalah kawula muda yang saat ini berusia antara 15-35 tahun.

Karakteristik generasi millenial ini secara umum ditandai oleh adanya progress yang menyebabkan mereka mahir dalam menggunakan teknologi, sehingga mereka cenderung lebih akrab dengan teknologi yang berkembang saat ini, salah satunya adalah penggunaan 
komunikasi lewat sosial media. Apabila dibandingkan dengan generasi sebelumnya, generasi millenial ini memiliki keunikan tersendiri. Ini dapat dilihat dari hasil riset yang dirilis oleh Pew Researh Center (Kompas.com, 2017), yang menjelaskan bahwa yang mencolok dari generasi millennial ini dibanding generasi sebelumnya adalah soal penggunaan teknologi dan budaya pop/musik. Penelitian ini memaparkan bahwa kehidupan generasi millennial sudah terikat dengan teknologi, sehingga teknologi ini menjadi kebutuhan pokok bagi generasi millenial.

Pemaparan di atas menunjukan bahwa era milenial ini memberikan kontribusi dan dampak tersendiri. Kontribusi yang dimaksud adalah apabila teknologi yang dimaksudkan di atas digunakan dalam kegiatan yang positif. Sebaliknya, teknologi akan memberikan dampak negatif apabila penggunanya tidak mampu menyesuaikan diri dan larut dalam perkembangan zaman. Adapun salah satu penggunaan teknologi yang dimaksud adalah konsumsi terhadap internet. Dalam konteks Indonesia, hal yang sama juga terjadi. Hasil survei yang dilakukan oleh Alvara Research Center tahun 2014 menunjukkan bahwa generasi yang lebih muda, 15 - 24 tahun lebih menyukai topik pembicaraan yang terkait musik/film, olahraga, dan teknologi. Sementara generasi yang berusia $25-34$ tahun lebih variatif dalam menyukai topik yang mereka perbincangkan, termasuk didalamnya sosial politik, ekonomi, dan keagamaan (CNN Indonesia, 2018). Selanjutnya, konsumsi internet penduduk kelompok usia 15-34 tahun juga jauh lebih tinggi dibanding dengan kelompok penduduk yang usianya lebih tua. Hal ini menunjukkan bahwa mereka memiliki ketergantungan terhadap koneksi internet sangat tinggi.

Selanjutnya, menurut Severin dan Tankard mengungkapkan sejumlah penelitian tentang dampak dan pemanfaatan internet menunjukkan bahwa internet menjadi sumber utama untuk belajar tentang apa yang sedang terjadi di dunia seperti untuk hiburan, bergembira, relaksasi, untuk melupakan masalah, menghilangkan kesepian, untuk mengisi waktu sebagai kebiasaan dan melakukan sesuatu dengan teman atau keluarga (Hardyanti, 2017).

Di kalangan remaja Indonesia, khususnya dari tingkat SMP dan SMA, internet sudah bukan hal yang asing lagi. Berdasarkan hasil survey yang diadakan oleh Spire Research \& Consulting mengungkapkan bahwa para remaja sebagai salah satu pengguna internet belum mampu memilah aktivitas internet yang bermanfaat, dan cenderung mudah terpengaruh oleh lingkungan sosial tanpa mempertimbangkan terlebih dahulu efek positif atau negatif yang akan diterima saat melakukan aktivitas internet tertentu. Hal ini memaparkan bahwa kecenderungan pengguna internet telah berhasil mengenyampingkan nilai-nilai moral dan etika (Rahardiyan, 2016).

Selanjutnya, Ki Hajar Dewantara mengatakan bahwa "pendidikan adalah daya upaya untuk memajukan bertumbuhnya budi pekerti (kekuatan batin, karakter), pikiran (intellect) dan tubuh anak, sehingga bagian-bagian itu tidak boleh dipisahkan agar kita dapat memajukan kesempurnaan hidup anak kita." Ini menegaskan bahwa dunia pendidikan memiliki kontribusi dalam membangun generasi millenial. Sudah menjadi rahasia umum jika generasi millenial cenderung beperilaku pragmatis dan instan. Hal ini perlu disadari bersama bahwa dalam menyikapi masalah ini perlu dilakukan langkahlangkah konkrit supaya tujuan dari Pendidikan Nasional tetap konsisten dengan mengikuti era millenial ini.

Konselor merupakan salah satu praksis pendidikan yang berperan dalam membantu siswa dalam mencapai tugas perkembangan secara optimal. Hal ini menegaskan bahwa Konselor adalah pendidik, dan pendidik merupakan tenaga profesional yang bertugas merencanakan dan melaksanakan proses pembelajaran, menilai hasil pembelajaran, 
melakukan pembimbingan dan pelatihan, serta melakukan penelitian dan pengabdian kepada masyarakat, serta konselor adalah pelaksana pelayanan konseling di sekolah (Depdiknas, 2003, 2006).".

Sebagai seorang pendidik, konselor memiliki tanggung jawab untuk membimbing siswa agar mencapai kemandirian dan perkembangan yang optimal. Ini menegaskan adanya tuntutan bagi konselor pada era milenial untuk mampu mengikuti perkembangan zaman dan dimanifestasikan dalam memberikan pelayanan-pelayanan kepada siswa sebagai konseli. Konselor diharapkan mampu melakukan pelayanan bimbingan dan konseling sebagai salah satu upaya pendidikan untuk membantu siswa dalam mencapai tugas perkembangan yang optimal. Harapan ini selanjutnya bermuara kepada peranan konselor dalam proses pendidikan. Artinya, konselor memegang peran penting dalam menyiapkan siswa di era millenial untuk berkontribusi dalam menyongsong perkembangan zaman. Dengan sistem pendidikan yang baik, diharapkan lahir generasi millenial berkualitas yang dapat membangun peradaban bangsa, dan mampu memajukan bangsa di masa depan. Berdasarkan latar belakang di atas, timbul beberapa pertanyaan, yaitu: (1) Bagaimana eksistensi konselor di era millenial; (2) Bagaimana wujud nyata peranan konselor profesional untuk pendidikan masa kini.

\section{METODE}

Metode yang penulis lakukan dalam penelitian adalah penelitian kepustakaan (library research), karena sumber data yang digunakan adalah seutuhnya berasal dari perpustakaan atau dokumentatif, yakni mengkaji sumber data yang terdiri dari literatur-literatur yang berkaitan dengan tema penelitian ini. Selanjutnya pengolahan data dalam penelitian ini menggunakan metode deskriptif-analitis, yaitu model penelitian yang berupaya mendeskripsikan, mencatat, menganalisa dan menginterpretasikan kondisi-kondisi yang ada sehingga diharapkan memberi gambaran pada eksistensi konselor di era millenial sebagai bentuk manifestasi pendidikan masa kini.

\section{HASIL DAN PEMBAHASAN}

Konselor merupakan tenaga profesional yang memiliki kualifikasi profesional spesialis dalam bidang bimbingan dan konseling. Urgensinya disini adalah konselor berperan dalam melaksanakan konseling, baik secara individual, kelompok, maupun secara klasikal. Pelaksanaan layanan ini nantinya menjadi kontribusi nyata konselor dalam dunia pendidikan, terutama siswa di sekolah. Dalam melaksanakan perannya, konselor bekerja secara fleksibel dan memiliki kemampuan dalam mengetahui bagaimana cara menghadapi siswa yang sedang dalam tahap perkembangan. Setiap siswa memiliki keunikan masingmasing, sehingga konselor harus mampu memahami bagaimana situasi dan langkah apa yang harus ditempuh.

Konselor merupakan salah satu praksis pendidikan. Ini termaktub dalam Undangundang Republik Indonesia Nomor 20 Tahun 2003 tentang Sistem Pendidikan Nasional BAB I Pasal 1 Ayat 6 yang menyatakan bahwa "pendidik adalah tenaga kependidikan yang berkualifikasi sebagai guru, dosen, konselor, pamong belajar, widyaiswara, tutor, instruktur, fasilitator dan sebutan lainnya sesuai dengan kekhususannya, serta berpartisipasi dalam penyelenggaraan pendidikan". Selanjutnya ditegaskan juga bahwa konselor adalah pendidik profesional yang berkualifikasi akademik minimal Sarjana Pendidikan (S-1) dalam bidang Bimbingan dan Konseling dan telah lulus Pendidikan Profesi Guru Bimbingan dan Konseling (Peraturan Menteri Pendidikan dan Kebudayaan Nomor 111 Tahun 2014 tentang Bimbingan 
dan Konseling Pada Pendidikan Dasar dan Pendidikan Menengah, 2014).

Undang-undang dan peraturan di atas memaparkan bahwa konselor sebagai pendidik profesional memiliki tugas untuk melaksanakan layanan konseling yang merupakan salah satu upaya dalam membantu siswa memperkembangkan dirinya secara optimal sesuai dengan tahap-tahap perkembangannya dan tuntutan lingkungan. Kemudian, konselor juga ikut andil dalam membantu siswa mengaktualisasikan dirinya secara optimal, baik dalam aspek kecerdasan intelektual, kecerdasan emosional, kecerdasan spritual, dan kecerdasan sosial, sehinga diharapkan nantinya siswa berhasil menjadi individu yang mandiri dan menjadi elemen dari sistem sosial yang saling berinteraksi dan mendukung satu sama lain. Ini mengindikasikan bahwa konselor memiliki peranan yang nyata dan mantap untuk mencapai tujuan pendidikan. Dalam rangka mewujudkan peranan ini, bimbingan dan konseling menjadi wahana bagi konselor untuk berkontribusi memfasilitasi dan mewujudkan proses pendidikan yang selaras dengan perkembangan zaman, terutama di era millenial ini.

Perkembangan zaman saat ini menuntut perkembangan profesi bagi konselor dalam memberikan layanan kepada siswa di sekolah. Tuntutan ini selaras dengan kompetensi yang dimiliki oleh konselor, terutama terkait dengan standar kinerja pada bidang-bidang layanan. Menurut ASCA (Nur et al., 2017), standar kerja untuk konselor sekolah berada pada domain: program, kurikulum bimbingann sekolah diberikan untuk seluruh siswa, perencanaan siswa secara individual, pelayanan-pelayanan responsif, dukungan sistem, kolaborasi konselor sekolah dan kepala sekolah, badan penasehat, pemakaian data, pemantauan siswa, penggunaan waktu dan penanggalan, evaluasi hasil, audit program dan pemasukan tema. Ini menjelaskan bahwa sebagai tenaga yang profesional, konselor harus mampu merancang, menganalisis, mengidentifikasi dan melaksanakan program-program secara benar dan tepat.

Era millenial merupakan istilah untuk tatanan peraraban manusia modern yang menjadikan teknologi sebagai sahabat dalam menjalankan aktifitas sehari-hari. Perkembangan teknologi ini selanjutnya tidak hanya mengatasi masalah, namun juga menimbulkan masalah baru akibat tergesernya tatanan kehidupanmanusia. Dalam lingkup yang lebih kecil, fenomena ini memberikan warna tersendiri bagi siswa di sekolah. Perilaku yang ditampilkan siswa dapat dilihat dari dua sisi, sisi positif dan sisi negatif. Pada sisi positif, siswa mampu mengakses informasi lebih cepat, sehingga dalam penggunaan teknologi ini, sisa lebih kreatif, inovatif dan mampu mengembangkan dirinya. Sebaliknya, pada sisi negatif, dampak dari kreativitas ini menjadikan siswa memiliki kecanduan dalam menggunakan teknologi, terutama ketika memiliki gadjet. Mereka dengan mudah mengakses konten-konten tertentu yang kurang mendidik.

Konselor sebagai bagaian dari komponen pendidikan ikut andil dalam menyikapi situasi ini. Konselor memiliki tanggung jawab dalam membimbing siswa agar tidak menyalah norma dan nilai yang berlaku. Hal ini dapat diwujudkan konselor dari program yang dirancang. Artinya, program yang disusun berumuara nantinya kepada proses membantu siswa untuk mengahadapi era millenial. Program yang dimaksud memiliki materi-materi yang edukatif serta menarik bagi siswa. Konselor dengan kompetensi yang dimilikinya dituntut untuk ikut serta menghadapi perkembangan zaman, terutama mengikuti perkembangan siswa. Sebagai individu yang sedang menjalankan pendidikan, siswa diberikan kebermanfaatan pelaksanaan layanan untuk dapat memfilterisasi dampak yang terjadi pada era millenial ini.

Pada hakikatnya, profesi konselor merupakan profesi yang dinamis, selalu berkembang, menyenangkan, berhubungan dengan tragei manusia dan kemungkinan dalam 
cara yang intensif, personal dan perhatian (Glading, 2012). Ini menjelaskan bahwa konselor menjadi suatu profesi yang berkontribusi dalam perkembangan manusia, khususnya siswa di era millenial, sehingga ini menuntut konselor harus mampu memahami realitas yang ada. Analoginya, tidak hanya perkembangan teknologi saja yang harus diikuti oleh konselor, namun esensialnya disini adalah permasalahan yang timbul seiring dengan perkembangan teknologi tersebut.

Profesi konselor di era millenial ini diharapkan menjadi profesi yang disenangi oleh masyarakat, terutama siswa. Manifestasinya disini adalah bagaimana konselor mampu mewujudkan tujuan pendidikan dalam pelaksanaan layanan di sekolah. Konselor harus mampu menjadikan 'era millenial' ini sebagai peluang untuk menghadapi siswa di sekolah. Sebagai salah satu komponen pendidikan, konselor yang profesional bertanggung jawab dalam mewujudkan pendidikan yang bermakna dalam pengembangan siswa di sekolah, terutama terkait dengan kepribadian dan watak siswa. Pada akhirnya, manifestasi ini mengisyaratkan bahwa profesi konselor memiliki kontribusi untuk berperan mengayomi siswa dalam menghadapi era milenial, artinya perkembangan yang dialami oleh siswa hendaknya selaras dengan keterlaksanaan program konseling di sekolah dalam rangka mewujudkan tujuan pendidikan. Pelaksanaan konseling dikemas dengan prosedur yang efektif dan efisien dan memiliki ketertarikan bagi siswa. Program ini selanjutnya juga selaras dengan koridor dan nilai-nilai yang berlaku yang terintegrasi dengan perkembangan era millenial yang sedang dihadapi siswa. Manifestasi inilah yang menjadi muara proses konseling dalam rangka mewujudkan eksistensi konselor di ranah pendidikan.

\section{KESIMPULAN}

Pendidikan di era millenial menuntut setiap komponen pendidikan untuk mampu membaca peluang, terutama konselor. Konselor sebagai inidvidu yang profesional mengemban tanggung jawab untuk mengiringi siswa dalam tahap perkembangannya. Tahap yang dimaksud salah satunya dipengaruhi oleh lingkungan. Siswa di rekolah rentan dengan kecanggihan teknologi. Mereka dapat mengakses dengan cekatan konten apa yang mereka ingin lihat. Kemampuan yang dimiliki siswa ini hendaknya menjadi bahan pertimbangan bagi konselor dalam melaksanakan perannya sebagai salah satu praksis pendidikan. Siswa sebagai individu yang berkembang dan sedang menjalankan proses pendidikan hendaknya diberi bekal untuk dapat memfilterisasi kemajuan zaman, terutama kecanggihan teknologi era millenial ini. Baik kontribusi dan dampak yang ditimbulkan hendaknya menjadi acuan bagi siswa untuk dapat memilah milih konten yang ingin di akses. Pelaksanaan program kegiatan bimbingan dan konseling ikut andil dalam pemilihan ini. Konselor yang profesional hendaknya memiliki keterampilan dan mampu mensiasasi materi-materi edukatif yang disenangi siswa dan mampu dirasakan kebermanfaatannya oleh siswa. Artinya, konselor dengan keterampilan yang dimilikinya hendaknya mampu menyelaraskan kemampuan siswa di era millenial ini, terutama dalam memberdayakan teknologi sebagai manifestasi pendidikan masa kini.

\section{REFERENSI}

CNN Indonesia. (2018). Survei Alvara: Sebagian Milenial Setuju Khilafah. CNN Indonesia. https://www.cnnindonesia.com/nasional/20180307191320-20-281228/survei-alvarasebagian-milenial-setuju-khilafah 
Depdiknas. (2003). Undang-undang Republik Indonesia Nomor 20 Tahun 2003 Tentang Sistem Pendidikan Nasional. Depdiknas.

Depdiknas. (2006). Peraturan Menteri Pendidikan Nasional Nomo 22 Tahun 2006. Depdiknas.

Glading, S. . (2012). Konseling Profesi yang Menyeluruh. Index.

Hardyanti, W. (2017). Diskrepansi Kepuasan Pembaca Media Online Islam: Studi Komparatif Kesenjangan Kepuasan Membaca Situs eramuslim.com di Kalangan Dosen dan Mahasiswa di Malang. Jurnal Sosial Politik, 3(1), 180-201. https://doi.org/10.22219/sospol.v3i1.4968

Peraturan Menteri Pendidikan dan Kebudayaan Nomor 111 Tahun 2014 tentang Bimbingan dan Konseling Pada Pendidikan Dasar dan Pendidikan Menengah, (2014).

Kompas.com. (2017). Rebut Hati Generasi Milenial dengan Cara Ini. Kompas.com. https://ekonomi.kompas.com/read/2017/08/28/182251126/rebut-hati-generasi-milenialdengan-cara-ini

Nur, R. M., Hidayah, Elia, E. F. Z., Boli, F. B., \& Hambali, L. I. (2017). Komitmen Pada Kode Etik Profesional. In Pendidikan dan Pelatihan Profesi Guru. Kemeterian Pendidikan dan Kebudayaan.

Rahardiyan, E. (2016). Pemanfaatan Internet Dan Dampaknya Pada Pelajar Sekolah Menengah Atas Di Surabaya. Jurnal Unair. 